\title{
Defining new technological traditions of Late Islamic Arabia: a view on Bahlā Ware from al-Ain (UAE) and the lead-barium glaze production
}

\author{
Jelena Živković ${ }^{1}$ (1) $\cdot$ Timothy Power $^{2} \cdot$ Myrto Georgakopoulou $^{1} \cdot$ José Cristobal Carvajal López $^{3}$
}

Received: 2 November 2018 / Accepted: 4 February 2019 / Published online: 16 March 2019

(C) The Author(s) 2019

\begin{abstract}
In this paper, the monochrome glazed Bahlā Ware from al-Ain dated between the seventeenth and twentieth centuries (Late Islamic Arabian Period) has been analysed aiming to reconstruct the production technology of the ceramic fabrics and glazes. The results of the petrographic and chemical analyses suggest a unique technological tradition embedded in the culture of Late Islamic Arabia. This tradition incorporates the production of a lead-barium glaze coated over a single type of ceramic fabric that spans for nearly three centuries. Since this is the first evidence for the production of a lead-barium glaze in the Islamic World, the origins of this technology remain uncertain, but the results of the ceramic petrography identify the Omani Peninsula as the most likely source for the ceramic fabric. During the economic peak of al-Ain in the eighteenth century, this tradition shows signs of technological diversity visible in the appearance of new fabrics and glazes. Considering the wide distribution of Bahlā Ware in the Western Indian Ocean, understanding of the production technology and provenance of al-Ain's ceramics has important implications for archaeological interpretation.
\end{abstract}

Keywords Bahlā Ware · Lead-barium glaze · Ceramic technology · Islamic ceramics · South East Arabia

\section{Introduction}

Scientific data presented in this paper are obtained in a pilot project designed to set the stage for the extensive research on ceramic production and technology in Late Islamic Arabia. The material under study is the monochrome class of Bahlā Ware, found in consumption contexts at al-Ain dated between the middle of the seventeenth- and the early twentieth centuries. The focus here is particularly on the lead-barium glaze that has been identified for the first time in the context of Islamic ceramics. Considering the lack of production debris

Electronic supplementary material The online version of this article (https://doi.org/10.1007/s12520-019-00807-6) contains supplementary material, which is available to authorized users.

Jelena Živković

j.zivkovic.12@ucl.ac.uk

1 UCL Qatar, Georgetown Building 2nd floor, P.O. Box 25256, Doha, Qatar

2 College of Humanities and Social Sciences, Zayed University, P.O. Box 144534, Abu Dhabi, UAE

3 University of Leicester, University Road, Leicester LE1 7RH, UK that can be linked with this ceramic class, the reconstruction of production practices starts with an in-depth analysis of consumed pottery.

\section{Bahlā Ware, the Oases of al-Ain and the regional context}

Bahlā Ware constitutes a class of monochrome glazed ceramics dominated by open bowl forms. It was first identified by Andrew Williamson as part of his survey of the Mīnāb Plain, the land behind the great Late Islamic Iranian emporium of Hormuz, published posthumously by Seth Priestman (2005), pp. 269-70, 2013, pp. 631-32). Williamson thought it was produced in the town of Khunj, in the hinterland of Bandar Lengeh, in southern Iran (Fig. 1). However, Priestman notes that no wasters were found among the sherds collected by Williamson, implying that Khunj is unlikely to have been the production centre. Conversely, this class is widely found in South East Arabia and it has alternatively been suggested that it was a product of the well-known kilns of Bahlā, a large oasis town in central Oman, which remained in use until the 1970s (Whitcomb 1975, p. 129; Priestman 2008, pp. 277-78, Plate 12). This identification seems 


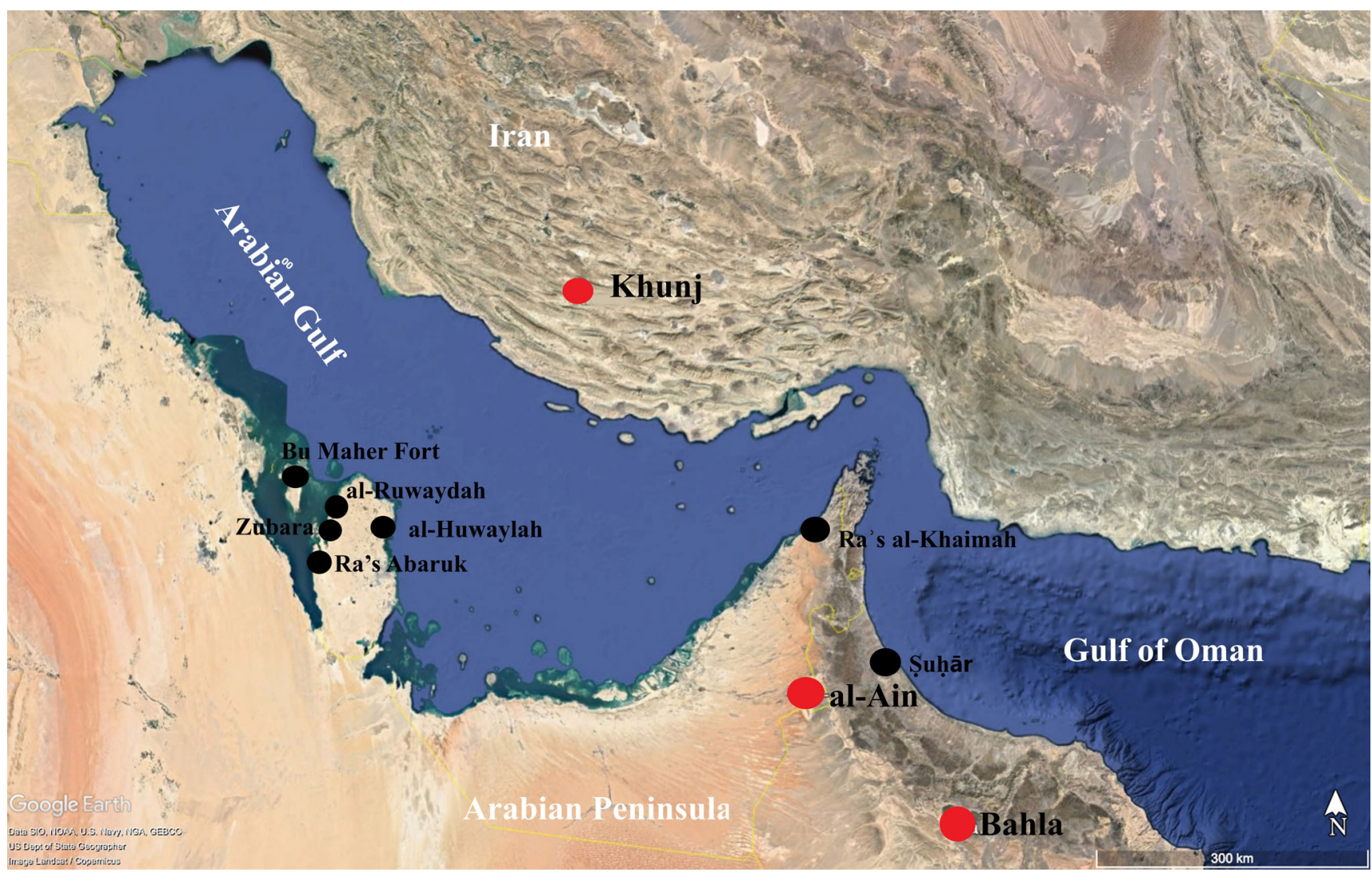

Fig. 1 The map showing locations of major sites of al-Ain, Bahlā, Khunj and other archaeological sites discussed in the paper

supported by a quantified study of the Late Islamic assemblage in the oases of al-Ain, further north along the same plain wherein Bahlā is situated, where this class represents as much as $48 \%$ of the glazed assemblage (Power 2015, p. 29, Table 26).

If the production centre in South East Arabia can be established, Bahlā Ware becomes a key marker of Omani trade in the early modern period. It is widely found at Late Islamic sites in the Arabian Gulf and western Indian Ocean between the sixteenth and twentieth centuries. Well-published instances in the UAE and Oman include Ra s al-Khaimah (de Cardi et al. 1994, p. 63; Kennet 2004, pp. 54-55), al-Ain (Power and Sheehan 2011, 2012; Power 2015), and Șuhār (Costa and Wilkinson 1987). It is commonly found in Qatar, at Zubara and al-Ruwaydah (Petersen et al. 2010, p. 48), Ra's Abaruk (Garlake 1978a, p. 167) and al-Huwaylah (Garlake 1978b, p. 174), and also in Bahrain, at the Bu Maher Fort (Kennet 2004, p. 54; Carter et al. 2011, pp. 90-91). Importantly, it has also been found at sites in East Africa, including Gedi (de Cardi and Doe 1971, pp. 266-67) and Fort Jesus (Kirkman 1974).

The present study focuses on a sample of Bahlā Ware from excavations at the Bin Ātî House in Qattāara Oasis, one of seven palm plantations which make up the historic Buraimi Oasis (Power and Sheehan 2012), today split by an international border into the towns of al-Ain (UAE) and Buraimi
(Oman). The oases of al-Ain occupy a strategic crossroads in the northern Omani Peninsula. They lie on a north-south axis between Ra s al-Khaimah and the Iranian Plateau beyond, on the one hand, and the Dhāhira Plain extending south to central Oman and the great oasis town of Bahlā on the other. To the east, the Wādī al-Jizī cuts through the Hajar Mountains to gain access to the Indian Ocean networks via the port of Șuhār, whilst the road west crosses the tip of the Rub al-Khālī to reach the pearling towns of Abu Dhabi and Dubai.

Excavations at the Bin Ātī House revealed three archaeological horizons (HRZ) associated with the Late Islamic occupation (Table 1). HRZ 9.1 (c.1650-1720) witnessed the construction of a large mudbrick tower house, probably contemporary with the creation of the adjacent palm plantation (Power and Sheehan 2012, p. 299, Fig. 6), which further included a date-press (madbasa). HRZ 9.2 (c. 1720-1790) marks an expansion of settlement and construction of a second house near the original tower; the quantity and quality of ceramic and coin finds suggest that this phase represents the peak of occupation. HRZ 10 (c. 1870-1920) constitutes a partial and perhaps seasonal reoccupation following a period of abandonment. Whilst the presence of other ceramic imports fluctuated over time, sometimes quite dramatically, it is striking that Bahlā Ware remains a consistent and slowly growing component of the assemblage. 
Table 1 The stratigraphic and chronological context of the Bahla samples from al-Ain (see Power 2015)

\begin{tabular}{llll}
\hline Code & Archaeological horizon & Chronology & Number of selected samples \\
\hline B1-22 & HRZ 9.1 & c. $1650-1720$ & 10 \\
B23-272 & HRZ 9.2 & c. $1720-1790$ & 28 \\
B273-288 & HRZ 10 & c. $1870-1920$ & 6 \\
\hline
\end{tabular}

\section{Materials and methodology}

\section{Sampling}

The sampling strategy followed in this paper has been designed to explore long-term patterns in the technology. For this purpose, 44 samples, out of 288 Bahlā Ware potsherds documented at Bin 'Ātī House, were selected for petrographic examination (Table 1). Drawing on the results of ceramic petrography, a number of sub-samples were subjected to chemical analyses both of the ceramic fabrics and the glazes as well as lead isotope analysis of the glazes. The aim was to investigate the compositional patterns, detecting potential variations between the glazes applied over fabrics with the same or different petrographic characteristics.

Samples belong to open bowls (40) and jars (4), reflecting the relative abundance of these types in the original assemblage. All vessels are wheel-made and coated with glaze on the external (jars) or both (bowls) sides. The colour of the glazes ranges between brown, yellow and green-all three were included in the sampling (Fig. 2).

\section{Thin section ceramic petrography}

Ceramic petrography was used for the petrological and textural characterisation of 44 samples. Thin sections of ceramics were observed with polarising microscopes LEICA DM750P and LEICA DM2500P in transmitted plain polarised (PPL) and cross polarised light (XPL). Fabric groups were defined by the petrology of their main inclusions, their distribution and texture (Whitbread 1989, 1995, pp. 365-96).

\section{Elemental analysis of fabrics and analysis of glazes}

Further research on the relations between fabrics was carried out by means of wavelength-dispersive X-ray fluorescence analysis (WDXRF), on a BRUKER S8 TIGER with a 4-kW Rh X-ray tube at the Fitch Laboratory of the British School at Athens. A calibration dedicated to the analysis of ancient ceramics was used for quantification, measuring in total 26 elements (Georgakopoulou et al. 2017). In total, 16 samples of the Bahlā Ware were analysed, all prepared as glass beads.
For the glaze analysis of 17 representative samples, a scanning electron microscope (SEM: JEOL JSM 6610LV) with an attached energy dispersive spectrometer (EDS: Oxford Instruments X-max ${ }^{\mathrm{N}} 50$ operated with the Aztec software) was used. Cross-sections of the samples were mounted in resin and polished to $1 / 4 \mu \mathrm{m}$. The Bahlā glazes are often heterogeneous, and thus the analysis included bulk measurements and separate measurements of the glassy matrix as well as individual inclusions. The bulk composition measurements included the glaze with randomly spread inclusions, excluding bubbles and pores to the extent that this was possible. The reported results represent the average values for 5 areas, standardised at approximately $100 \times$ $120 \mu \mathrm{m}$ using $\times 800$ magnification. For comparison, the analysis of the glaze matrix, avoiding the inclusions, is included. An average of 3-5 scans of an arbitrary size is reported, depending on the glaze texture. Furthermore, the composition of the various inclusions was measured with EDS spot analysis. The analyses were run in high vacuum conditions, at an accelerated voltage of $20 \mathrm{kV}$, working distance $10 \mathrm{~mm}$, process time 5 , and acquisition time $60 \mathrm{~s}$ livetime. A cobalt standard was measured periodically to monitor the beam current and the spot size was adjusted around 59 to achieve $40 \%$ deadtime on the cobalt metal. The performance of the instrument was monitored using the Corning Glass Standard C (Brill 1999, p. 542). Precision, estimated as relative standard deviation, was found to be within $3 \%$ for major elements and deteriorated as concentration approaches the detection limits of the EDS at around $0.1 \%$. The relative difference of the mean to the certified value $(\delta \%)$ is within $5 \%$ for most elements, with the exception of barium and lead where it is within $10 \%$ and cobalt whose composition approached the detection limits of the instrument and the difference is $13 \%$.

\section{Lead isotope analysis of glazes}

Lead isotope analysis was performed on 5 samples of glazes to investigate the provenance of the lead-rich component. For this purpose, a small amount of glaze (c. $150 \mathrm{mg}$ ) was scraped off as a powder. The isotopic measurements were carried out at Frankfurt University, under the supervision of Dr. S. Klein, using a multicollector-inductively coupled plasma-mass spectrometer (MC-ICP-MS) Neptun TM Finnigan MAT (for details of the methodology see Klein et al. 2009). 

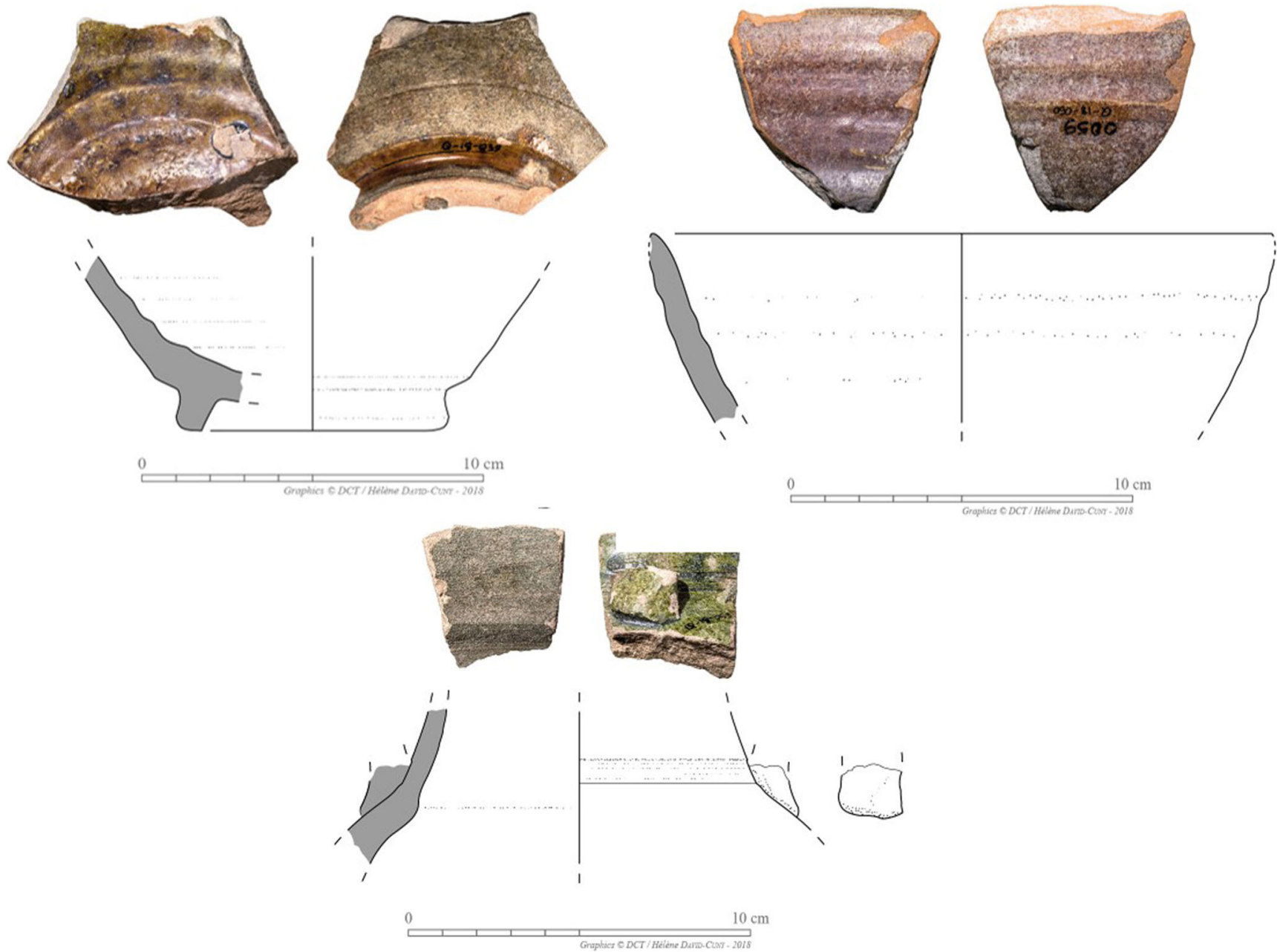

Fig. 2 Reconstruction of representative vessels of Bahla Ware from al-Ain, coated with green, brown and yellow monochrome glazes

\section{Results}

\section{The results of ceramic petrography}

The results of ceramic petrography show that Bahlā Ware from al-Ain can be classified into a single fabric group, with two related samples and two petrographic loners (Appendix A). The ceramics are fine, with more than $90 \%$ of the inclusions occurring in the fine fraction.

Out of 44 analysed samples, 40 can be classified into the Limestone and Serpentinite fabric group (LS), defined by the presence of these two rocks set in a calcareous matrix (Appendix A; Fig. 3). The fabric is also characterised by detritic minerals consistent with an igneous geology of mafic or ultramafic rocks, such as clinopyroxene, plagioclase and olivine. This indicates that the raw clay was collected from a sedimentary environment where those minerals are deposited. The internal variability in the abundance of limestone, serpentinite and minerals associated with igneous rocks makes this fabric to some extent heterogenous.
The remaining four samples are petrographically diverse (Appendix A). All four samples have a bimodal distribution of inclusions, which indicates a different preparation of paste recipes compared to the LS fabric group. Apart from this common technological trait, the samples show a range of petrographic differences. Samples B132 and B252 contain rare inclusions of igneous rock/s, serpentinized in B252 (Fig. 4(a, b). Although these two samples have common inclusions in the coarse fraction, which makes them to some extent related, their relative quantity varies, making the degree of their relation uncertain. They also show a petrological association with the LS fabric group, considering the igneous nature of the inclusions in coarse fraction, but the different distribution of those inclusions (unimodal vs bimodal) is evident. B60 and B106 are described as petrographic loners because they contain even less inclusions that can indicate petrographic relations between them and the rest of the assemblage. The petrology of B106 is consistent with the LS fabric group, but the scarcity of inclusions in the coarse fraction prevent further 
Fig. 3 Limestone Serpentinite fabric group (LS). Sample B32 in PPL (left) and XPL (right) with inclusions of quartz, limestone and serpentinite set in a calcareous matrix

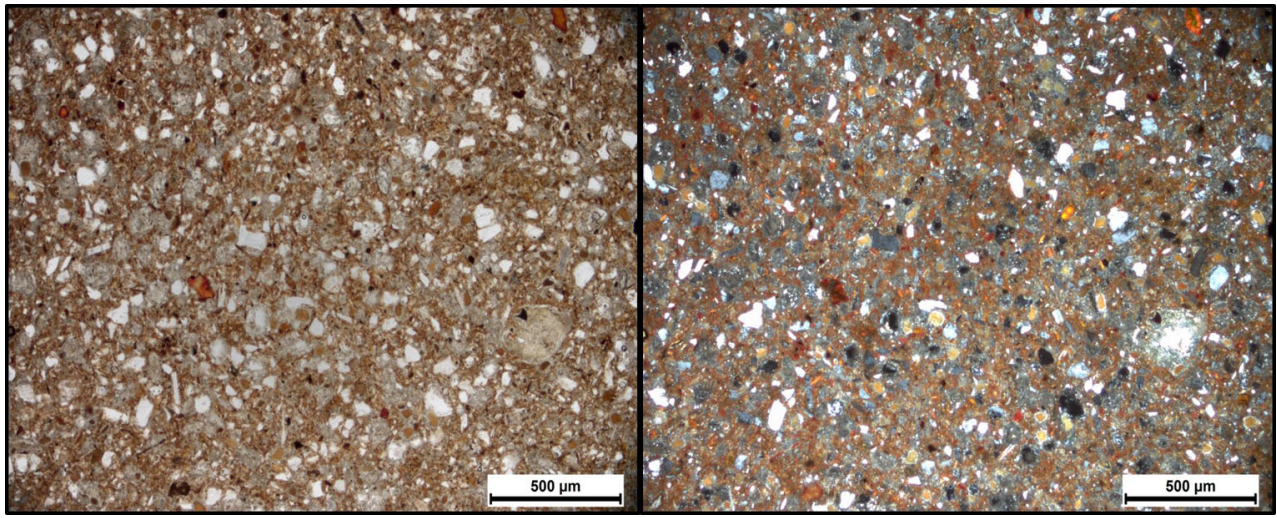

interpretation (Fig. 4(c). The same applies to B60, which is poor in inclusions in both the coarse and the fine fractions (Fig. 4(d).

Overall, the petrology of all four samples is in the same geological range with the LS fabric group, indicating exploitation of similar secondary clays. All analysed samples show well-controlled firing conditions as no colour differences can be observed in individual sherds. The equivalent firing temperature, based on the optical activity of the clay matrix, can be estimated to $c .800-850{ }^{\circ} \mathrm{C}$.

\section{The chemical composition of ceramics}

The results of WDXRF analysis are given in Table 2. Prior to pulverising the samples, the glaze layer was removed using a slow-speed saw with a thin diamond-coated blade and the external surfaces of the sherds were subsequently further cleaned with a tungsten-carbide drill. Still, the presence of significant contents of lead (Table 2) in the results suggests that part of the glaze layer was present in the pulverised sample. This will have affected a number of other elements in unpredictable ways as the glaze contamination is likely to be variable and the glaze compositions were also shown to be relatively heterogeneous. These elements are $\mathrm{Ba}$, as will be shown below the glazes are $\mathrm{Pb} / \mathrm{Ba}$ rich, as well as $\mathrm{Cu}$ present as a colourant in some cases. These three elements $(\mathrm{Pb}, \mathrm{Ba}$ and $\mathrm{Cu}$ ) are thus disregarded in the elemental grouping of ceramics. $\mathrm{FeO}$ is also present as a colourant in the glaze, but as this is a major element in the ceramic body, it is assumed that the traces of glaze contamination would not affect the overall iron content very much. The Th $\mathrm{L} \alpha$ measured by the WDXRF partially overlaps the $\mathrm{Pb} \mathrm{L} \beta$. Although this is taken into
Fig. 4 Samples B132 (a), B252 (b), B60 (c) and B106 (d) that differ from the LS fabric group. Inclusions of igneous origin are visible on images $a$ and $b$ whilst images $\mathrm{c}$ and $\mathrm{d}$ show only inclusions of fine quartz. All images are given in XPL

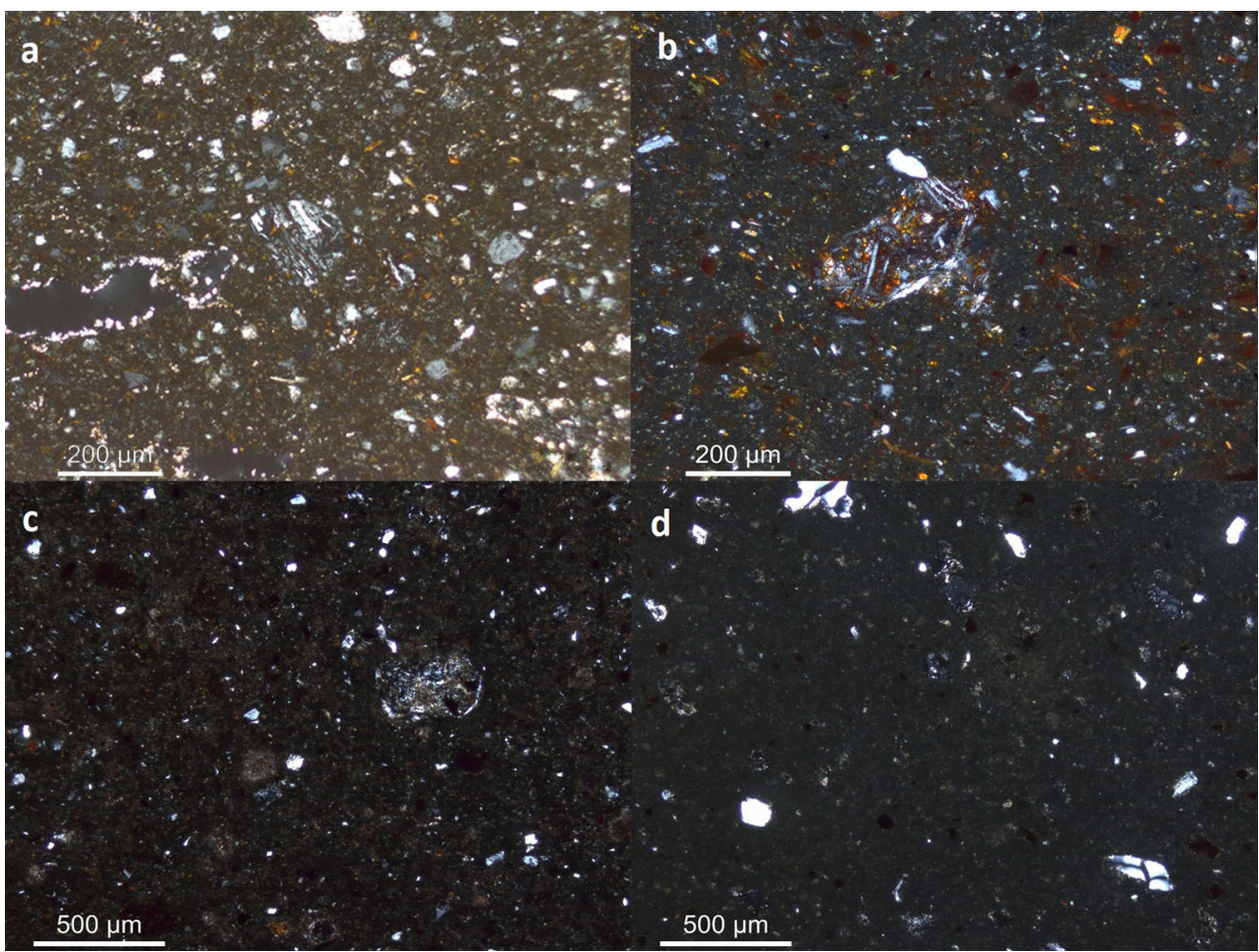




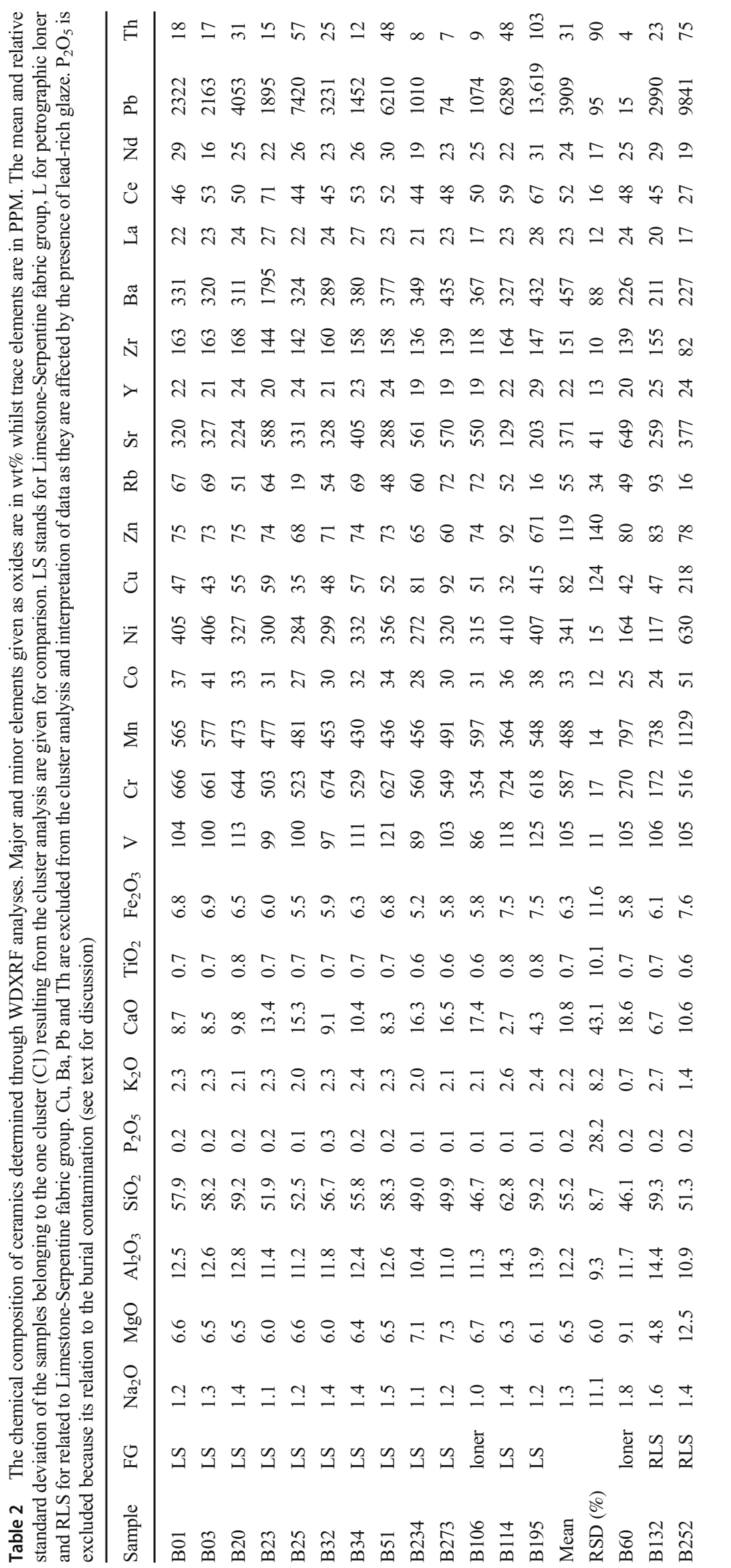


account with an overlap correction in the Th calibration (Georgakopoulou et al. 2017), the lead contents in the Bahlā ceramics far exceed the standards used in the WDXRF calibration, and the correlation of $\mathrm{Pb}$ to $\mathrm{Th}$ values noted in the elemental results (Table 2), suggests the thorium contents are not reliable. They were thus disregarded as well and so was $\mathrm{P}_{2} \mathrm{O}_{5}$ that is associated with the burial contamination of archaeological ceramics (Freestone et al. 1985).

The cluster analysis performed on the raw chemical data additionally supports the heterogeneous character of Bahlā Ware, as the results of ceramic petrography suggest. Relations between the analysed samples are presented on the dendrogram (Fig. 5). One cluster emerges from the dendrogram (C1), consisting of samples of the LS fabric group and the petrographic loner B106. Slight compositional differences between the samples of $\mathrm{C} 1$, primarily in the $\mathrm{CaO}$ content (Table 2), are illustrated on the dendrogram. Excluding B114 and B195, the samples of $\mathrm{C} 1$ are calcareous, with the $\mathrm{CaO}$ content ranging between 8.3 and $17.4 \mathrm{wt} \%$. However, similarities of other components suggest they should be seen as one group with varying $\mathrm{CaO}$ values. $\mathrm{B} 114$ and $\mathrm{B} 195$ are low-calcareous samples, with correspondingly higher contents of $\mathrm{SiO}_{2}, \mathrm{Al}_{2} \mathrm{O}_{3}$ and $\mathrm{Fe}_{2} \mathrm{O}_{3}$. Sr, which is geochemically associated with $\mathrm{Ca}$, is also lower, whilst $\mathrm{Cr}$ and $\mathrm{Ni}$, associated with the serpentinitic component are increased. Furthermore, the value of $\mathrm{Zn}$ in B195 is affected by the glaze contamination being exceptionally high here and should thus be disregarded. It is thus clear that the two samples are rightly considered part of the same cluster, with the chemical distinctions noted here being a result of relative proportions of the different components.

The remaining three samples (B60, B132 and B252) can be described as outliers (Table 2; Fig. 5). Differences in major, minor and trace elements illuminate compositional differences compared to the samples of $\mathrm{C} 1$.

\section{The chemical composition of glazes}

The chemical characterisation of the glazes determined through SEM-EDS shows that most samples of the LS fabric group are coated with a lead-barium glaze (Table 3 ). This is a glaze of heterogenous texture, as illustrated on the SEM photomicrographs (Fig. 6). The thickness of the glaze layer ranges between 80 and $200 \mu \mathrm{m}$. Quartz inclusions of various sizes are randomly scattered through the glaze, sometimes causing cracks in the texture (A on Fig. 6). Non-dissolved fragments of barium sulphate or baryte $\left(\mathrm{BaSO}_{4}\right)$ could be detected in the form of bright inclusions, ranging in size from small $(20 \times 20 \mu \mathrm{m})$ rounded particles to large $(100 \times 100 \mu \mathrm{m})$ subangular lumps (B on Fig. 6). The thickness of the ceramicglaze interface varies significantly, and in the case of $\mathrm{BaO}$-rich glazes (B106) cannot be defined because the entire glaze layer is largely crystalline. The glaze is characterised by several crystalline phases of various compositions. The most abundant are Ca-rich pyroxenes, averaging $19.5 \mathrm{at} \% \mathrm{Si}, 8.8 \mathrm{at} \%$ $\mathrm{Ca}, 6.8 \%$ atMg and $4.0 \%$ atFe, with minor amounts of $\mathrm{Na}$, $\mathrm{Al}, \mathrm{K}, \mathrm{Ba}$ and $\mathrm{Pb}$; some of these most likely also measured from the surrounding glaze. The composition of these crystals ranges between that of diopside $\left(\mathrm{CaMgSi}_{2} \mathrm{O}_{6}\right)$ and hedenbergite $\left(\mathrm{CaFeSi}_{2} \mathrm{O}_{6}\right)$ and they form at the ceramicglaze interface and/or float freely in the glaze ( $\mathrm{C}$ on Fig. 6). Another crystalline phase, appearing brighter than the matrix in backscatter mode (D on Fig. 6) shows higher contents of $\mathrm{Ba}(4.2$ at\%), as well as $\mathrm{Si}(18.8$ at\%), $\mathrm{Fe}$ (7.3at\%), $\mathrm{Al}(4.4 \mathrm{at} \%)$, and $\mathrm{Mg}, \mathrm{K}$ and $\mathrm{Ca}$ at around 1 at $\%$. Their extremely small size precludes their individual analysis, as the surrounding matrix is also incorporated, so a direct identification of the mineralogy of these crystals is not attempted here. Furthermore, iron-rich clusters are occasionally present in the glaze.
Fig. 5 Cluster dendrogram resulting from the cluster analysis performed on all samples included in the WDXRF analysis, using raw chemical compositions. Excluded oxides and elements are $\mathrm{P}_{2} \mathrm{O}_{5}, \mathrm{Cu}, \mathrm{Ba}, \mathrm{Pb}$ ad Th

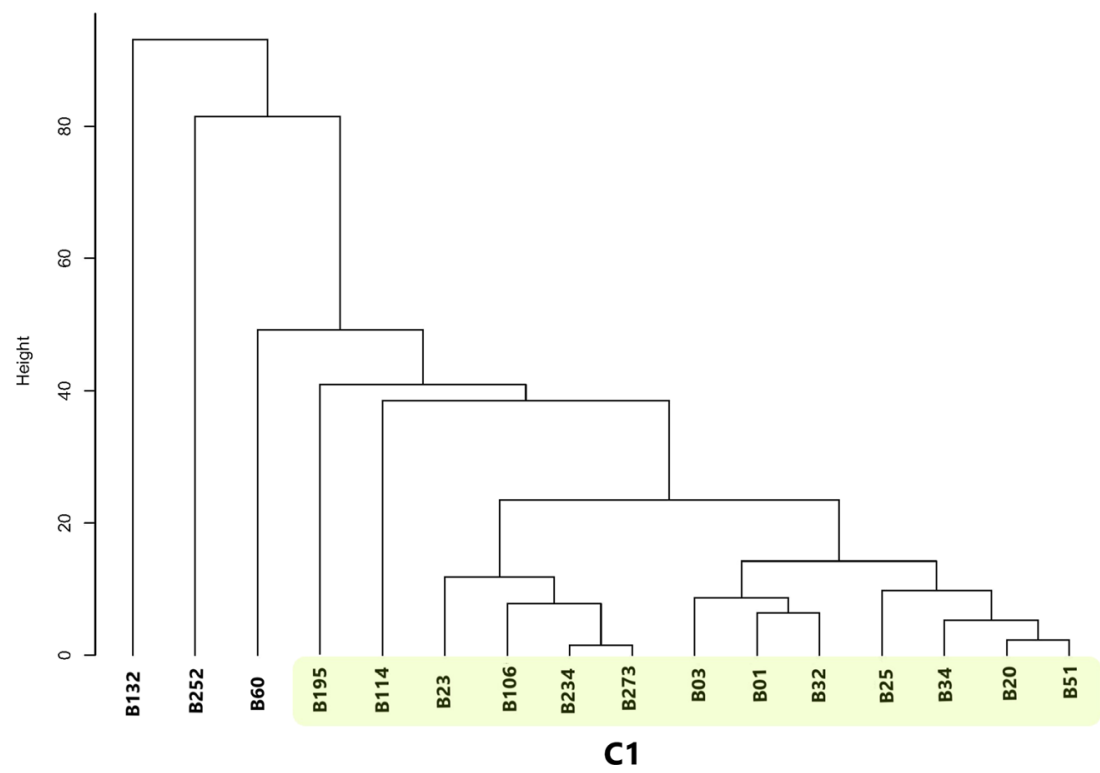


Table 3 The chemical composition of glazes determined through the SEM-EDS analysis. All results are normalised to $100 \mathrm{wt} \%$. '-'indicates below detection limits. LS stands for the Limestone-Serpentine fabric group and RLS for related to Limestone-Serpentine fabric group

\begin{tabular}{|c|c|c|c|c|c|c|c|c|c|c|c|c|c|c|c|c|c|}
\hline Sample & FG & Colour & $\mathrm{Na}_{2} \mathrm{O}$ & $\mathrm{MgO}$ & $\mathrm{Al}_{2} \mathrm{O}_{3}$ & $\mathrm{SiO}_{2}$ & $\mathrm{P}_{2} \mathrm{O}_{5}$ & $\mathrm{~K}_{2} \mathrm{O}$ & $\mathrm{CaO}$ & $\mathrm{TiO}_{2}$ & $\mathrm{MnO}$ & $\mathrm{FeO}$ & $\mathrm{CuO}$ & $\mathrm{ZnO}$ & $\mathrm{SnO}_{2}$ & $\mathrm{BaO}$ & $\mathrm{PbO}$ \\
\hline B1 bulk & & & 1.1 & 3.0 & 4.7 & 44.7 & 0.3 & 2.2 & 7.2 & - & - & 12.0 & & & - & 15.4 & 9.0 \\
\hline B1 matrix & LS & Yellow & 1.1 & 1.2 & 2.7 & 45.2 & & 1.9 & 3.6 & & & 12.1 & 0.2 & & & 14.4 & 17.7 \\
\hline B3 bulk & & & 1.4 & 1.3 & 3.0 & 45.3 & - & 3.3 & 3.9 & & - & 9.8 & - & - & - & 10.2 & 21.8 \\
\hline B3 matrix & LS & Yellow & 1.4 & 1.0 & 2.9 & 47.5 & & 3.7 & 3.1 & & & 10.3 & & & & 9.0 & 21.1 \\
\hline B8 bulk & & & 1.3 & 2.3 & 3.0 & 43.5 & - & 1.4 & 6.3 & - & - & 9.8 & 0.2 & - & - & 11.1 & 20.8 \\
\hline B8 matrix & LS & Brown & 1.5 & 0.5 & 3.2 & 40.0 & & 1.5 & 3.7 & & & 10.1 & & & & 14.0 & 25.6 \\
\hline B16 bulk & & & 1.1 & 2.1 & 1.8 & 36.2 & 0.2 & 1.5 & 4.0 & - & - & 9.3 & 0.8 & - & - & 8.2 & 34.8 \\
\hline B16 matrix & LS & Brown & 0.9 & 1.4 & 1.6 & 35.7 & & 1.4 & 2.5 & & & 9.5 & 0.5 & & & 7.7 & 38.9 \\
\hline B20 bulk & & & 1.3 & 1.3 & 1.8 & 33.7 & - & 1.7 & 4.4 & & - & 10.4 & - & - & - & 6.4 & 39.0 \\
\hline B20 matrix & LS & Brown & 0.9 & 1.2 & 1.5 & 34.1 & & 1.4 & 2.7 & & & 9.0 & & & & 5.7 & 43.5 \\
\hline B25 bulk & & & 1.5 & 2.0 & 2.4 & 36.3 & - & 1.9 & 6.6 & - & - & 8.0 & - & - & - & 6.7 & 34.5 \\
\hline B25 matrix & LS & Brown & 1.6 & 0.5 & 2.3 & 34.1 & & 2.1 & 4.3 & & & 7.7 & & & & 7.4 & 40.2 \\
\hline B32 bulk & & & 1.1 & 1.0 & 2.4 & 46.4 & - & 2.3 & 3.4 & - & - & 9.5 & 0.2 & - & - & 9.2 & 24.5 \\
\hline B32 matrix & LS & Yellow & 1.4 & 0.9 & 1.4 & 43.4 & & 2.9 & 2.9 & & & 11.7 & & & & 9.8 & 25.7 \\
\hline B34 bulk & & & 1.3 & 1.3 & 1.3 & 46.2 & - & 3.1 & 3.4 & - & - & 11.6 & - & - & - & 10.5 & 21.4 \\
\hline B34 matrix & LS & Yellow & 1.5 & 1.0 & 1.2 & 44.2 & & 3.2 & 2.7 & & & 12.0 & & & & 11.2 & 23.0 \\
\hline B106 bulk & LS & Yellow & 0.8 & 2.9 & 5.7 & 48.7 & - & 2.9 & 8.3 & - & - & 13.5 & - & - & - & 12.4 & 4.5 \\
\hline B114 bulk & & & 1.1 & 2.3 & 4.8 & 41.8 & - & 1.5 & 3.1 & & - & 5.3 & - & - & - & 4.3 & 35.9 \\
\hline B114 matrix & LS & Yellow & 1.1 & 1.3 & 4.3 & 39.9 & & 1.4 & 1.5 & & & 5.6 & & & & 4.4 & 40.6 \\
\hline B150 bulk & & & 1.4 & 2.3 & 2.6 & 40.0 & - & 1.4 & 6.3 & - & - & 9.2 & - & - & - & 12.0 & 24.7 \\
\hline B150 matrix & LS & Brown & 1.4 & 0.6 & 2.7 & 36.5 & & 1.5 & 3.7 & & & 8.8 & & & & 14.0 & 30.8 \\
\hline B279 bulk & & & 1.2 & 1.1 & 2.9 & 39.2 & - & 2.2 & 2.5 & & - & 11.4 & - & - & - & 5.0 & 34.5 \\
\hline B279 matrix & LS & Yellow & 1.2 & 0.7 & 2.5 & 38.2 & & 2.2 & 1.7 & & & 8.8 & & & & 4.9 & 39.7 \\
\hline B281 bulk & & & 0.4 & 2.1 & 3.6 & 44.1 & 0.3 & 0.6 & 4.8 & - & - & 13.4 & - & - & - & 29.5 & 1.0 \\
\hline B281 matrix & LS & Yellow & 0.4 & 1.4 & 3.8 & 44.8 & & 0.6 & 3.6 & & & 12.1 & & & & 32.2 & 1.1 \\
\hline B287 bulk & & & 0.7 & 2.0 & 1.9 & 40.0 & & 1.0 & 4.3 & & - & 8.1 & - & - & - & 10.1 & 31.9 \\
\hline B287 matrix & LS & Yellow & 0.6 & 1.3 & 1.6 & 39.9 & & 0.8 & 3.5 & & & 8.1 & & & & 12.2 & 32.0 \\
\hline B195 bulk & & & 0.6 & 1.2 & 2.2 & 33.7 & - & 0.4 & 1.8 & - & - & 1.3 & 0.8 & 3.4 & - & 0.6 & 54.0 \\
\hline B195 matrix & LS & Green & 0.5 & 0.8 & 1.2 & 32.6 & & 0.4 & 1.3 & & & 1.3 & 1.5 & 3.7 & & 0.5 & 56.2 \\
\hline B252 bulk & & & 0.6 & 1.2 & 0.9 & 33.5 & - & 0.8 & 1.4 & 0.3 & 0.4 & 5.5 & - & - & 0.8 & - & 54.8 \\
\hline B252 matrix & RLS & Yellow & 0.6 & 1.2 & 0.8 & 33.1 & & 0.7 & 1.4 & 0.3 & 0.4 & 5.2 & & & 0.5 & & 55.9 \\
\hline B132 bulk & & & 0.6 & 0.9 & 4.1 & 32.9 & - & 0.9 & 4.0 & 0.2 & - & 4.7 & 0.3 & - & - & - & 51.5 \\
\hline B132 matrix & RLS & Yellow & 0.6 & 0.6 & 4.6 & 33.9 & & 1.2 & 3.0 & 0.2 & & 3.7 & 0.2 & & & & 52.3 \\
\hline
\end{tabular}

Fig. 6 SEM photomicrographs of lead-barium glazes detected on samples B3 (left) and B22 (right), taken in the BEC mode. Visible inclusions are quartz (A), baryte (B), Ca-rich pyroxenes $(\mathrm{C})$, and probably Ba-rich pyroxenes (D)

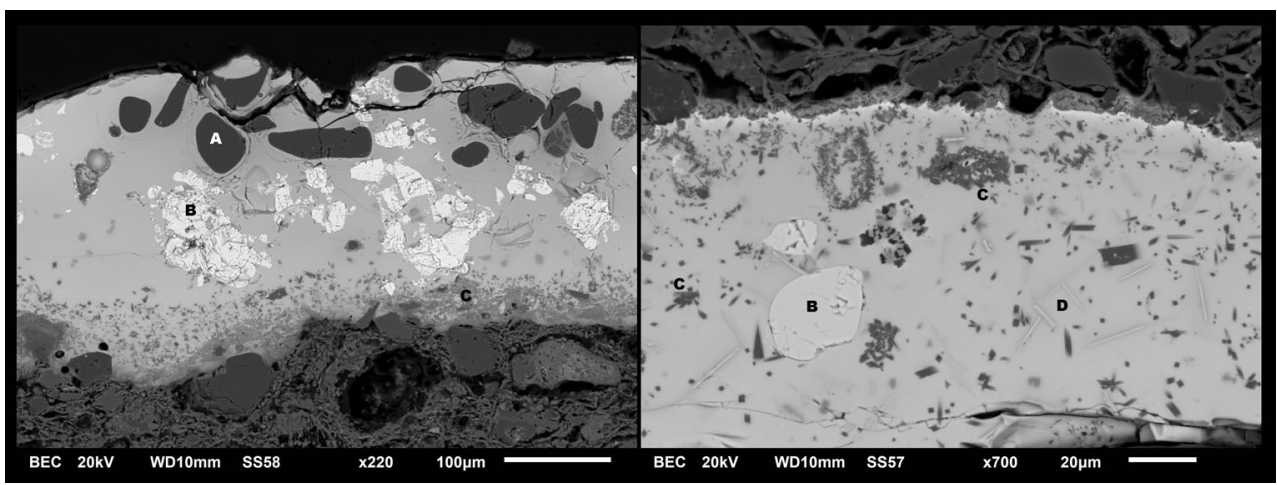


The chemical composition of the glaze shows a negative correlation between $\mathrm{PbO}(1-39 \%)$ and $\mathrm{BaO}(4.3-29.5 \%)$, implying that the two are mineralogically associated (Table 3). Furthermore, the glaze contains 33.7-57.4\% $\mathrm{SiO}_{2}, 2.5-8.3 \% \mathrm{CaO}, 1.8-5.7 \% \mathrm{Al}_{2} \mathrm{O}_{3}, 1-3 \% \mathrm{MgO}, 0.4-$ $1.5 \% \mathrm{Na}_{2} \mathrm{O}$ and $0.6-3.3 \% \mathrm{~K}_{2} \mathrm{O}$. The content of $\mathrm{FeO}$ is high (5.3-13.5\%), suggesting it was deliberately added as a colourant. The $\mathrm{CuO}$ value is $<1 \%$, which indicates it is probably an impurity associated with the lead minerals rather than a deliberately added colourant in the yellow and brown glazes.

An exception in the LS fabric group is B195 that contains a glaze of lead-zinc-barium type, whose chemical composition is characterised by $54 \% \mathrm{PbO}, 3.4 \% \mathrm{ZnO}, 0.6 \% \mathrm{BaO}, 33.7 \%$ $\mathrm{SiO}_{2}, 2.2 \% \mathrm{Al}_{2} \mathrm{O}_{3}, 1.8 \% \mathrm{CaO}, 1.2 \% \mathrm{MgO}$ and $1 \% \mathrm{Na}_{2} \mathrm{O}+$ $\mathrm{K}_{2} \mathrm{O}$ (Table 3). Compared to the group of lead-barium glazes, B195 has significantly less $\mathrm{BaO}$, which does not fit the correlation with $\mathrm{PbO}$ noted in the lead-barium glazes. This result might indicate the use of different raw materials. The texture is, on the other hand, similar to the lead-barium group, containing non-dissolved fragments of quartz as well as Ca-rich pyroxenes in the interface and glaze (Fig. 7).

Interestingly, the samples B132 and B252 that do not belong to the LS fabric group are coated with a high-lead glaze that contains no traces of $\mathrm{BaO}$ (Table 3 ). Both samples contain over $50 \%$ of $\mathrm{PbO}$ and around $33 \%$ of $\mathrm{SiO}_{2}$, but differ in the contents of $\mathrm{Al}_{2} \mathrm{O}_{3}$ and $\mathrm{CaO}$. Furthermore, $\mathrm{SnO}_{2}(0.8 \%)$ is detected in $\mathrm{B} 252$, visible as bright crystallites in the glaze (Fig. 7(c).

\section{Lead isotope analyses of the glazes}

Five glaze samples from the LS fabric group were analysed for their lead isotope ratios; one was B195, the lead-zincbarium glaze, whilst the other four were all typical leadbarium glaze samples (Table 4 ). The results show relative standard deviations between $0.22 \%$ for the ${ }^{208} \mathrm{~Pb} /{ }^{206} \mathrm{~Pb}$ ratio to $0.45 \%$ for ${ }^{206} \mathrm{~Pb} /{ }^{204} \mathrm{~Pb}$. Ore deposits of uniform geological and geochemical history are reported to have a spread of lead isotope ratios up to a maximum of $0.3 \%$ (Gale and Stos-Gale 1992) or even 0.6\% (Pernicka et al. 1990 , p. 283). In principle thus, the lead for all five samples could have been sourced from the same deposit. Sample B195 is, however, clearly separated from the other four (Fig. 8) which together with its different chemistry, probably indicates a different source.

\section{Discussion}

\section{Ceramic traditions of Late Islamic Arabia}

The scientific assessment of Bahlā Ware consumed in alAin offers evidence for continuity of a technological tradition that spans between the mid-seventeenth and the early twentieth centuries. This tradition is defined by the clear correlation between the LS fabric group and the leadbarium glaze, showing standardisation in all segments of the chaines opératoires. The transfer of knowledge and skills embedded in this tradition is telling of the cultural importance of Bahlā Ware for the communities settled in South East Arabia.

The technological diversity of Bahlā Ware is documented only in the eighteenth century (HRZ 9.2) at the Bin 'A $\bar{t} \overline{1}$ site. Although modest in number, the samples different to the LS fabric group indicate the presence of diverse technological practices, for both ceramics and glazes, that were used for manufacturing morphologically similar pots. The exploitation of similar secondary clays for the preparation of technologically different pastes coated with equally different glazes indicate the emergence of new workshops with distinctive practices.

\section{Lead-barium glaze in the Islamic world}

In the broad spectra of Islamic glazes and glasses in the Near East (e.g. Brill 2001; Freestone 2006; Tite 2011; Henderson 2013), the lead-barium glaze of Bahlā Ware has no parallels.

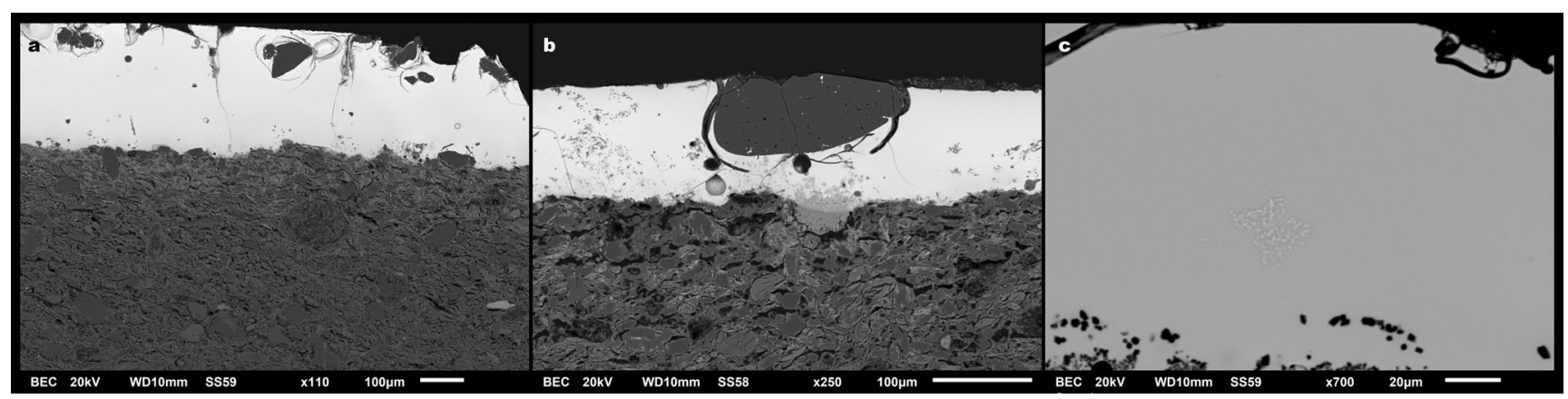

Fig. 7 SEM photomicrographs of lead-barium-zinc glaze of sample B195 (a) and high-lead glazes of samples B132 (b) and B252 (c) taken in BEC. Visible inclusions on images a and $\mathrm{b}$ are identified as quartz whilst image c contains inclusions of $\mathrm{SnO}_{2}$ 
Table 4 Lead isotope ratios of Bahla Ware from al-Ain

\begin{tabular}{llll}
\hline Samples & ${ }^{206} \mathrm{~Pb} /{ }^{204} \mathrm{~Pb}$ & ${ }^{207} \mathrm{~Pb} /{ }^{206} \mathrm{~Pb}$ & ${ }^{208} \mathrm{~Pb} /{ }^{206} \mathrm{~Pb}$ \\
\hline $\mathrm{B} 1$ & 18.11690 & 0.86542 & 2.11393 \\
$\mathrm{~B} 25$ & 18.11119 & 0.86502 & 2.11283 \\
$\mathrm{~B} 32$ & 18.11895 & 0.86525 & 2.11371 \\
$\mathrm{~B} 195$ & 18.30110 & 0.85831 & 2.10357 \\
$\mathrm{~B} 281$ & 18.13577 & 0.86529 & 2.11465 \\
RSD $(\%)$ & 0.45 & 0.36 & 0.22 \\
\hline
\end{tabular}

In fact, this type of glass is considered to be a Chinese innovation (Fuxi 2009, p. 20; Henderson 2013, p. 123; Henderson et al. 2018), and unknown outside of East Asia (Cui et al. 2011, p. 1671; Rehren and Freestone 2015, p. 234). Therefore, Bahlā Ware offers the first evidence for the production of lead-barium glaze in the Islamic World. In the absence of relevant analogies, the emergence and development of this glaze technology remain unclear. In the geographically close Iran, the seventeenth-century tiles of the Safavid period have glazes of the alkaline and lead types without traces of barium (Holakooei et al. 2014). The seventeenth-century Mughal tiles in India are coated with alkali glazes (Gill and Rehren 2011). Therefore, the lead-barium glaze of Bahlā Ware stands out from other contemporary traditions in the Islamic world.

The presented results enable a preliminary reconstruction of the lead-barium glaze technology and methods of application. The clear correlation between $\mathrm{PbO}$ and $\mathrm{BaO}$ determined through SEM-EDS supports their mineral association in nature. Baryte commonly occurs with lead sulphides such as galena. For the assessment of the original glaze composition and methods of application, the contents of $\mathrm{PbO}, \mathrm{BaO}$ and $\mathrm{CuO}$, oxides clearly coming from the glaze, were excluded from the analyses of the ceramic fabrics and glazes, and the remaining compositions were recalculated and normalised to 100\% (see Tite et al. 1998, pp. 249-250). The data presented in Table 5 show consistent differences in the compositions of bodies and glazes, for example, a significantly increased $\mathrm{Si} / \mathrm{Al}$ ratio in the glaze, suggesting that the glaze was applied as a lead/barium-silica mixture. Since the glaze contains large pieces of non-dissolved baryte and quartz, it is more likely that they were applied as a suspension directly on the body. Experiments conducted on high-lead glazes suggest a high firing temperature $\left(950{ }^{\circ} \mathrm{C}\right.$ and above) and slow cooling rate $\left(20^{\circ} \mathrm{C} / \mathrm{h}\right)$ for glazes showing an extended crystalline layer (Molera et al. 2001, pp. 1121-1122), which is the case with the Bahlā glazes. However, the reaction occurring between lead and baryte in glazes remains understudied, which precludes firm conclusions on the firing temperature. The sparkling look of the glaze, noticed by several scholars (Hansman 1985, p. 52; Kennet 2004, p. 42; Carter 2011, p. 37), could be explained by the presence of crystalline phases formed during devitrification. Finally, iron oxide was used as a colourant, which means that the colour gradient depends on the firing conditions.

It is challenging to explain the reasons for the use of sulphidic minerals in glaze preparation, as these are known for their poor fluxing properties (Brill et al. 1991b, p. 34). The role of deliberately added barium-bearing material in the early Chinese glasses was to achieve a jade-colour opacity (Brill et al. 1991b, p. 34; Cui et al. 2011, p. 1675), which was not needed in the case of the monochrome glazed Bahlā Ware. Also, it appears that $\mathrm{PbO}$ and $\mathrm{BaO}$ were part of the same naturally mixed batch and their amounts could not be controlled. A deliberate choice of the lead-barium compound as a raw material is indisputable, though. The lead isotope ratios dated to all three archaeological horizons in al-Ain suggest the exploitation of a single source for the lead-barium material. This continuity would not exist without a strong cultural association of craftsmen with this technological choice.

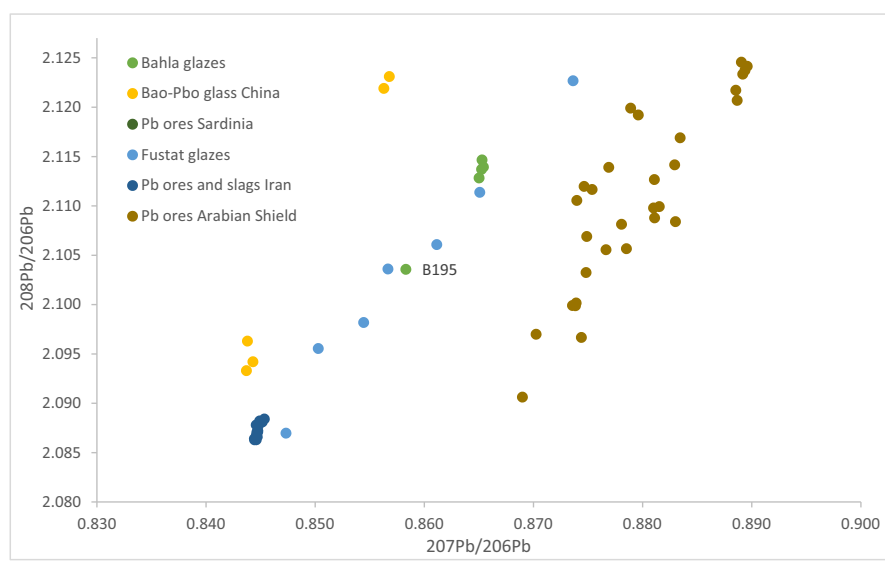

Fig. 8 The binary plot shows lead isotopes measured in five glazes of Bahla Ware (Table 4), compared with lead-barium glass from China (Cui et al. 2011), Pb ores from Sardinia (Stos-Gale et al. 1996; Gale 2011),

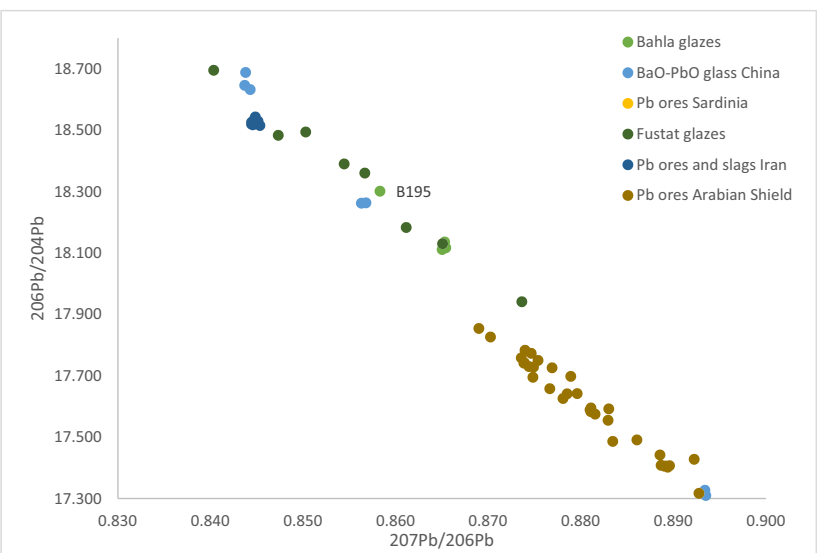

glazes from Fustat (Wolf et al. 2003), Pb ores and glazes from Iran (Pernicka et al. 2012) and $\mathrm{Pb}$ ores from the Arabian Shield (Stacey et al. 1980; Stacey and Stoeser 1983) 
Table 5 Chemical compositions (SEM-EDS) of bodies and glazes excluding $\mathrm{CuO}, \mathrm{BaO}$ and $\mathrm{PbO}$ in the latter and, normalised to $100 \mathrm{wt} \%$. "-'indicates below detection limits

\begin{tabular}{lllrlllrrr}
\hline Samples & $\mathrm{Na}_{2} \mathrm{O}$ & $\mathrm{MgO}$ & $\mathrm{Al}_{2} \mathrm{O}_{3}$ & $\mathrm{SiO}_{2}$ & $\mathrm{P}_{2} \mathrm{O}_{5}$ & $\mathrm{~K}_{2} \mathrm{O}$ & $\mathrm{CaO}$ & $\mathrm{TiO}_{2}$ & $\mathrm{FeO}$ \\
\hline B1 glaze & 1.5 & 3.9 & 6.3 & 59.5 & 0.4 & 2.9 & 9.6 & - & 16.0 \\
B1 body & 1.2 & 5.9 & 12.5 & 59.5 & - & 2.3 & 10.5 & 0.7 & 7.0 \\
B8 glaze & 2.0 & 3.4 & 4.5 & 64.2 & - & 2.1 & 9.3 & - & 14.5 \\
B8 body & 2.3 & 6.0 & 13.9 & 57.0 & - & 1.9 & 12.4 & 0.4 & 4.8 \\
B16 glaze & 1.9 & 3.7 & 3.2 & 64.5 & 0.4 & 2.7 & 7.0 & - & 16.5 \\
B16 body & 1.3 & 5.8 & 12.4 & 59.2 & - & 2.1 & 11.4 & 0.7 & 6.5 \\
B20 glaze & 2.4 & 2.5 & 3.4 & 61.8 & - & 3.0 & 8.0 & - & 19.0 \\
B20 body & 1.3 & 6.5 & 12.8 & 59.6 & - & 2.2 & 10.3 & 0.7 & 6.1 \\
B25 glaze & 2.6 & 3.4 & 4.1 & 61.9 & - & 3.2 & 11.2 & - & 13.6 \\
B25 body & 1.1 & 6.3 & 11.1 & 56.3 & - & 2.0 & 15.9 & 0.8 & 6.1 \\
B34 glaze & 1.9 & 1.9 & 1.9 & 67.8 & - & 4.6 & 4.9 & - & 17.0 \\
B34 body & 1.3 & 6.3 & 12.1 & 55.5 & - & 2.3 & 14.4 & 0.7 & 6.2 \\
B150 glaze & 2.2 & 3.6 & 4.2 & 63.2 & - & 2.2 & 10.0 & - & 14.6 \\
B150 body & 1.0 & 7.0 & 11.8 & 54.1 & - & 2.0 & 16.0 & 0.6 & 6.5 \\
B281 glaze & 0.6 & 3.0 & 5.2 & 63.5 & 0.5 & 0.9 & 6.9 & - & 19.3 \\
B281 body & 1.2 & 8.0 & 12.1 & 54.7 & 0.3 & 2.2 & 14.3 & 0.7 & 6.5 \\
B287 glaze & 1.2 & 3.4 & 3.2 & 69.0 & - & 1.8 & 7.5 & - & 13.9 \\
B287 body & 1.2 & 6.3 & 12.8 & 61.8 & - & 2.2 & 8.5 & 0.6 & 6.5 \\
\hline
\end{tabular}

\section{Ceramic provenance of the LS fabric group}

An efficient provenance study of archaeological pottery requires a holistic approach, including testing potential clay sources and their comparison with archaeological pottery (Tite 2001). In this case, designed to be a pilot study, largescale testing of clays was not feasible. Therefore, this preliminary provenance study relies on a comparison between the petrographic data and geological maps of Oman (Bechennec et al. 1986a, 1986b) and Iran (Spaargaren 1991).

The petrographic results point to an environment rich in limestone and serpentinite used for clay exploitation. The presence of limestone and rounded and sub-rounded quartz in the calcareous matrix suggest the formation of rocks by accumulation in a sedimentary basin, where detritic minerals associated with igneous rocks were deposited. Both petrographic and chemical compositional variations, such as the $\mathrm{CaO}$ variability, documented in the LS fabric group could be explained with this geological setting.

The petrology of the inclusions is consistent with the geological composition of the ophiolitic mountains in Oman (Lippard et al. 1986, p. 62), and more specifically with that of wadis that intersect rock formations (Hanna 1995). In semiarid environments, alluvial fans are formed during a movement of materials from upper to lower elevations, especially during humid seasons (Rapp and Hill 2006, pp. 63-64). The town of Bahlā, one of the potential production centres, lies on one of these wadis surrounded by the ophiolitic mountains (Bechennec et al. 1986a). Alluvial terraces, located just 5$7 \mathrm{~km}$ north of the modern town, contain abundant olistoliths of dolomite and biolithoclastic limestone, breccia and limestone with chert nodules, sandstone with calcareous matrix, serpentinized harzburgite and basalts (Bechennec et al. 1986b), and therefore could be a potential source of raw material. The historical and ethnographic importance of Bahlā for the regional ceramic production would support this possibility (Whitcomb 1975, p. 129). However, the absence of archaeologically documented production debris in the town obscures a more accurate identification.

With more certainty, it is possible to discard Khunj in Iran as a production centre for the Bahlā Ware consumed in al-Ain. Khunj is located in the anticline Fars domain of the Zagros Fold Belt, a region with sedimentary geology (Spaargaren 1991) and lies far beyond the ophiolitic zone (Momenzadehs 2004; Ghorbani 2013, pp. 47-50). Some other areas of Central Iran (High Zagros) are rich in ophiolites and geologically match the composition observed in the Bahlā Ware, but there is no archaeological evidence to suggest production of it there.

\section{Glaze provenance of the LS fabric group}

Although lead isotope analysis has been used for provenance determination of lead glasses for several decades (Brill and Wampler 1967), the method only recently started being used for the study of Islamic glazes (Wolf et al. 2003; Mason et al. 2011). The scarcity of comparable datasets for lead ores in the Middle East sets a limitation for absolute provenance attribution. This is especially relevant for this research; where the main subject of interest is the lead-barium mineralisation. 
Oman is rich in copper ores (Begemann et al. 2010), but leadbarium sources are not known. Extensive lead-barium mineralisation occurs in Central Iran and Alborz, always in association with zinc-lead ores (Ghorbani 2013, p. 169). However, the available isotope ratios for representative minerals in the zinclead deposits from Sanadaj-Sirjan, Urumeih-Dokhtar and the Zagros zones (Ehya et al. 2010; Mirnejad et al. 2011) do not match the Bahlā glazes (Fig. 8). Even more distant are lead ores, lead slags and litharge from the Central Iranian Plateau (Pernicka et al. 2012, p. 670). The same is true for lead ores in the Saudi Arabia shield (Stacey et al. 1980; Stacey and Stoeser 1983).

An overview of lead isotope ratios from distant China, which is usually associated with lead-barium glass and glaze production (Brill et al. 1991a; Cui et al. 2011), does not offer a match with the glazes from al-Ain (Fig. 8). The closest association can be made with the ores of galena, pyrite and baryte from Sardinia (StosGale et al. 1996; Gale 2011). Similarly, close ratios are reported for three glazed samples from Mamluk's Fustat dated to the fourteenth century (Wolf et al. 2003, p. 411). However, this proximity in lead isotope ratios does not provide an adequate framework for an archaeological interpretation of the provenance of Bahlā Ware, and may well be a consequence of random isotopic overlap (Henderson et al. 2005). In short, the absolute provenance of the lead-rich components of these glazes remains unknown.

\section{Conclusion}

This pilot project examines technological patterns of Bahlā Ware consumed in al-Ain between the mid-seventeenth and the early twentieth centuries in order to shed more light on the production and provenance of glazed ceramics in Late Islamic Arabia. The petrographic data presented here, together with those deriving from the archaeological investigations, indicate that Bahlā Ware is more likely to be the product of workshops located in Oman, possibly Bahlā itself, than Iran. This production was standardised and consisted of technological choices that were carefully transmitted from one generation of potters to the next over the course of three centuries. The peculiar aspect of this production refers to the glaze recipe, made of a lead/barium and silica mixture. Whilst the source of the lead-rich raw materials remains unclear due to the lack of comparable data, it is certain that the use of a mixed lead-barium mineral was a deliberate choice. The continuity in the exploitation of a single source, as the lead isotopes demonstrate, supports this conclusion. The chronological concentration of technological variability in the eighteenth century suggests the introduction of different workshops and technological solutions for the production of this ware, potentially related to increased regional demand. Further work will clarify whether this diversity is restricted to the eighteenth century or al-Ain only got access to multiple production networks in this period of economic peak.

A better grasp on the origins and technology of the leadbarium glaze in the Islamic World has to be sought within the regional context of Arabia and the Gulf. Further work is required into other assemblages dated to the Late Islamic period, including other classes besides Bahlā, as well as a holistic approach towards the question of production centres.

Acknowledgements We are grateful to Peter Sheehan for providing us with permission for sampling, Parviz Holakooei for giving valuable information about glazes and sources of raw materials in Iran, Martina Renzi and Michael Bode for guidelines and facilitating the lead isotope analysis and Thilo Rehren and Maninder Gill for comments and suggestions.

Open Access This article is distributed under the terms of the Creative Commons Attribution 4.0 International License (http:// creativecommons.org/licenses/by/4.0/), which permits unrestricted use, distribution, and reproduction in any medium, provided you give appropriate credit to the original author(s) and the source, provide a link to the Creative Commons license, and indicate if changes were made.

\section{References}

Bechennec F, Beurrier M, Hutin G, Rabu D (1986a) Bahla geological map, Sheet NF40-7A, 1: 100,000

Bechennec F, Beurrier M, Hutin G, Rabu D (1986b) Rustaq geological map, Sheet NF40-3D, 1:100,000

Begemann F, Hauptmann A, Schmitt-Strecker S, Weisgerber G (2010) Lead isotope and chemical signature of copper from Oman and its occurrence in Mesopotamia and sites on the Arabian Gulf coast. Arab Archaeol Epigr 21:135-169

Brill R (1999) Chemical analysis of early glasses. Volume 2, tables of analyses. The Corning Museum of Glass, New York

Brill R (2001) Some thoughts on the chemistry and technology of Islamic glass. In: Carboni S, Gudenrath W (eds) Glass of the sultans. The Metropolitan Museum of Art, New York, pp 25-46

Brill RH, Wampler JM (1967) Isotope studies of ancient lead. Am J Archaeol 71:63-77. https://doi.org/10.2307/501589

Brill R, Barnes L, Joel E (1991a) Lead isotope studies of early Chinese glasses. In: Brill R, Martin J (eds) Scientific research in early Chinese glass. Corning Museum of Glass, New York, pp 65-84

Brill R, Tong SCS, Dohrenwen D (1991b) Chemical analyses of some early Chinese glasses. In: Brill HR, Martin HJ (eds) Scientific research in early Chinese glass. Corning Museum of Glass, New York, pp 31-59

Carter R (2011) Ceramics of the Qatar National Museum. Report on behalf of the Qatar Museums Authority. Oxford Brookes University, Oxford

Carter R, Morley M, Morse C (2011) Bu Maher Fort, Muharraq. Report on excavations in 2010 for the Ministry of Culture and Information, Bahrain. Oxford Brookes Archaeology and Heritage, Oxford

Costa PM, Wilkinson TJ (1987) The hinterland of Sohar. Archaeological surveys and excavations within the region of an Omani seafaring city. J Oman Stud 9:1-238

Cui J, Wu X, Huang B (2011) Chemical and lead isotope analysis of some lead-barium glass wares from the Warring States Period, unearthed from Chu tombs in Changde City, Hunan Province, China. J Archaeol Sci 38:1671-1679

de Cardi B, Doe DB (1971) Archaeological survey in the Northern Trucial States. East West 21:225-289

de Cardi B, Kennet D, Stocks R (1994) Five thousand years of settlement at Khatt, UAE. Proc Semin Arab Stud 24:35-95

Ehya F, Lotfi M, Rasa I (2010) Emarat carbonate-hosted Zn-Pb deposit, Markazi Province, Iran: a geological, mineralogical and isotopic (S, $\mathrm{Pb}$ ) study. J Asian Earth Sci 37:186-194 
Freestone IC (2006) Glass production in Late Antiquity and the Early Islamic period: a geochemical perspective. Geomaterials Cult Herit 257:201-216

Freestone IC, Meeks ND, Middleton AP (1985) Retention of phosphate in buried ceramics: an electron microbeam approach. Archaeometry 27:161-177

Fuxi G (2009) Origin and evolution of ancient Chinese glass. In: Fuxi G, Brill R, Shouyu T (eds) Ancient glass research along the silk road. World Scientific Publishing, Singapore

Gale HN (2011) OXALID, Italy, filename Italian ores. In: Oxford Archaeol. Lead Isot. Database from Isotrace Lab. http://oxalid. arch.ox.ac.uk/default.html. Accessed 18 Feb 2017

Gale N, Stos-Gale Z (1992) Lead isotope studies in the Aegean. Proc Br Acad 77:63-108

Garlake PS (1978a) An encampment of the seventeenth to nineteenth centuries on Ras Abaruk, site 5. In: de Cardi B (ed) Qatar archaeological report. Excavations 1973. Oxford University Press, Oxford, pp 164-171

Garlake PS (1978b) Fieldwork at al-Huwailah, site 23. In: de Cardi B (ed) Qatar archaeological report. Excavations 1973. Oxford University Press, Oxford, pp 172-189

Georgakopoulou M, Hein A, Müller N, Kiriatzi E (2017) Development and calibration of a WDXRF routine applied to provenance studies on archaeological ceramics. X-Ray Spectrom 46:186-199

Ghorbani M (2013) The economic geology of Iran, mineral deposits and natural resources. Springer Science \& Business Media, Berlin

Gill MS, Rehren T (2011) Material characterization of ceramic tile mosaic from two 17th-century Islamic monuments in northern India. Archaeometry 53:22-36

Hanna S (1995) Geology of Oman. The Historical Association of Oman, Ruwi

Hansman J (1985) Julfar, an Arabian port: its settlement and far eastern ceramic trade from the 14th to the 18th centuries. The Royal Asiatic Society of Great Britain and Ireland, London

Henderson J (2013) Ancient glass an interdisciplinary exploration. Cambridge University Press, Cambridge

Henderson J, Evans JA, Sloane HJ, Leng MJ, Doherty C (2005) The use of oxygen, strontium and lead isotopes to provenance ancient glasses in the Middle East. J Archaeol Sci 32:665-673

Henderson J, An J, Ma H (2018) The archaeometry and archaeology of ancient Chinese glass: a review. Archaeometry 60:88-104

Holakooei P, Tisato F, Vaccaro C, Petrucci FC (2014) Haft rang or cuerda seca? Spectroscopic approaches to the study of overglaze polychrome tiles from seventeenth century Persia. J Archaeol Sci 41:447-460

Kennet D (2004) Sasanian and Islamic pottery from Ras al-Khaimah. Classification, chronology and analysis of trade in the Western Indian Ocean. Archaeopress, Oxford

Kirkman JS (1974) Fort Jesus: a Portuguese fortress on the East African Coast. Clarendon Press, Oxford

Klein S, Domergue C, Lahaye Y et al (2009) The lead and copper isotopic composition of copper ores from the Sierra Morena (Spain). J Iber Geol 35:59

Lippard JS, Shelton WA, Gass GI (1986) The ophiolite of Northern Oman. Blackwell Scientific Publications, Oxford

Mason RB, Farquhar RM, Smith PE (2011) Lead-isotope analysis of Islamic glazes: an exploratory study. Muqarnas 9:67-71. https:// doi.org/10.2307/1523136

Mirnejad H, Simonetti A, Molasalehi F (2011) Pb isotopic compositions of some $\mathrm{Zn}-\mathrm{Pb}$ deposits and occurrences from Urumieh-Dokhtar and Sanandaj-Sirjan zones in Iran. Ore Geol Rev 39:181-187

Molera J, Pradell T, Salvado N, Vendrell-Saz M (2001) Interactions between clay bodies and lead glazes. J Am Ceram Soc 84:1120-1128

Momenzadehs M (2004) Metallic mineral resources of Iran, mined in ancient times. A brief review. In: Stollner T, Slotta R, Vatandoust A (eds) Persian antiques splendor, mining crafts and metalurgy in ancient Iran. Deutsches Bergbau-Museum Bochum, Bochum, pp 8-22

Pernicka E, Begemann F, Schmitt-Strecker S, Grimanis AP (1990) On the composition and provenance of metal artefacts from Poliochni on Lemnos. Oxford J Archaeol 9:263-298

Pernicka E, Adam K, Bohme M et al (2012) Archaeometallurgical research on the western Central Iranian Plateau. In: Votandoust A, Parzinger H, Helwing B (eds) Early mining and metallurgy on the Western Central Iranian Plateau: the first five years of work. Philipp von Zabern, Mainz

Petersen A, Grey T, Rees C, Edwards I (2010) Excavations and survey at al-Ruwaydah, a late Islamic site in northern Qatar. Proc Semin Arab Stud 40:41-53

Power T (2015) A first ceramic chronology for the Late Islamic Arabian Gulf. J Islam Archaeol 2:1-33

Power T, Sheehan P (2011) The Bayt Bin Ātī in Qaț̣ārah Oasis: a prehistoric industrial site and the formation of the oasis landscape of alAin, UAE. Semin Arab Stud 41:267-282

Power T, Sheehan P (2012) The origin and development of the oasis landscape of al-Ain (UAE). Proc Semin Arab Stud 39(42):291-308

Priestman SMN (2005) Settlement and ceramics in the Southern Iran: an analysis of the Sasanian and Islamic periods in the Williamson Collection. University of Durham, Durham

Priestman SMN (2008) Islamic pottery in Oman. In: Al-Salimi A, Gaube H, Korn L (eds) Islamic art in Oman. Mazoon Printing, Muscat, pp 260-281

Priestman S (2013) A quantitative archaeological analysis of ceramics exchange in the Persian Gulf and Western Indian Ocean AD c.400-1275. University of Southamption, Southamption

Rapp G, Hill CL (2006) Geoarchaeology, the earth-science approach to archaeological interpretation, 2nd edn. Yale University Press, New Haven and London

Rehren T, Freestone I (2015) Ancient glass: from kaleidoscope to crystal ball. J Archaeol Sci 56:233-241

Spaargaren F (1991) Geological map of south and Southwest Iran, scale 1:1000 000. Robertson Group, Llandudno

Stacey JS, Stoeser DB (1983) Distribution of oceanic and continental leads in the Arabian-Nubian Shield. Contrib Mineral Petrol 84:91-105

Stacey JS, Doe BR, Roberts RJ, Delevaux MH, Gramlich JW (1980) A lead isotope study of mineralization in the Saudi Arabian Shield. Contrib Mineral Petrol 74:175-188

Stos-Gale Z, Gale NH, Annetts N (1996) Lead isotope data from the isotrace laboratory, Oxford: Archeometry data base 3, ores from the Aegean, part 1. Archaeometry 38:381-390

Tite MS (2001) Overview - materials study in archaeology. In: Brothwell DR, Pollard M (eds) Handbook archaeological sciences. John Wiley \& Sons, LTD, Chichester, pp 443-449

Tite MS (2011) The technology of glazed islamic ceramics using data collected by the late Alexander Kaczmarczyk. Archaeometry 53:329-339

Tite MS, Freestone I, Mason R et al (1998) Lead glazes in antiquity-methods of production and reasons for use. Archaeometry 40:241-260

Whitbread IK (1989) A proposal for the systematic descriptions of thin sections towards the study of ancient ceramic technology. In: Archaeometry. Proceedings of the 25th International Symposium (Amsterdam). pp 127-38

Whitbread IK (1995) Greek transport amphorae, a petrological and archaeological study. The British School at Athens, Athens

Whitcomb D (1975) The archaeology of Oman: a preliminary discussion of the Islamic periods. J Oman Stud I:123-157

Wolf S, Stos S, Mason R, Tite MS (2003) Lead isotope analyses of Islamic pottery glazes from Fustat, Egypt. Archaeometry 45:405-420

Publisher's note Springer Nature remains neutral with regard to jurisdictional claims in published maps and institutional affiliations. 